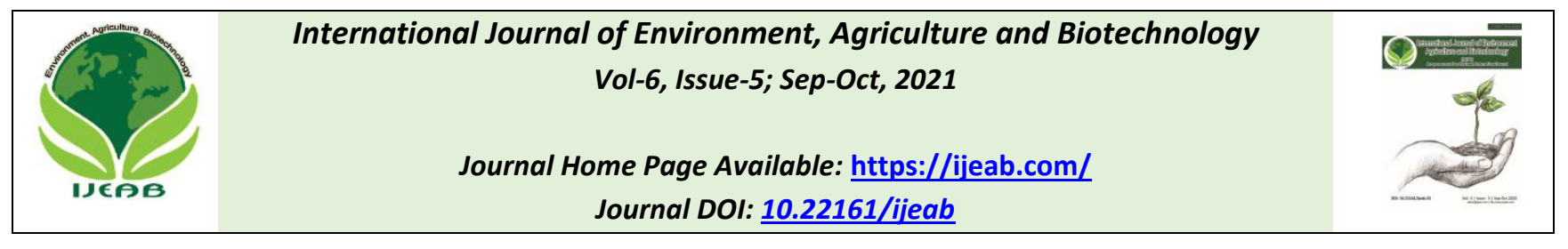

\title{
Effect of Intra Row Spacing on the Growth and Yield of Maize (Zea Mays L.) Varieties in Southern Guinea Savanna of Nigeria
}

\author{
Ekwere Uwem Akpan*; Ezelobe Courage Afegheze; Durkwah Godiya Young
}

National Biotechnology Development Agency, Abuja

*Corresponding Author

Received: 11 Sep 2021; Received in revised form: 18 Oct 2021; Accepted: 25 Oct 2021; Available online: 31 Oct 2021

(C)2021 The Author(s). Published by Infogain Publication. This is an open access article under the CC BY license

(https://creativecommons.org/licenses/by/4.0/).

\begin{abstract}
This study was carried out at the Research Farm of the Faculty of Agriculture, University of Abuja on latitude $6^{\circ} 45^{\prime}$ and $7^{\circ} 39^{\prime}$ East and Longitude $8^{\circ} 25^{\prime}$ and $9^{\circ} 20^{\prime}$ North in the Southern Guinea Savanna Zone of Nigeria, during the cropping season of 2018 to evaluate the effects of intra-row spacing on growth and yield of maize varieties. Two hybrid maize varieties Dekalb920 and Dekalb 818 sourced from National Seed Council of Nigeria were evaluated under six different intra-row spacing's of $14 \mathrm{~cm}$, 18,21,25,30, and 37cm, with gross plot of $15 \mathrm{~m}$ and net plot of $9 \mathrm{~m}$ for such Parameters as plant height, number of leaves, leaf area/index, stem diameter and grain yield. It was a factorial combination experiment laid out in a Randomized Complete Block Design (RCBD) with three replicates. The results obtained during the 12th week after sowing indicated that hybrid variety Dekalb920 which had mean plant height of $273.06 \mathrm{~cm}$, number of leaves of 16, leaf area of $734 \mathrm{~cm} 2$ and grain yield of 8,0t/ha among other parameters was superior to Dekalb818 variety investigated. With respect to intra-row spacing, plants sown on $14 \mathrm{~cm}$ had higher mean plant height and number of leaves of $287.7 \mathrm{~cm}$ and 16, respectively while plants sown on intra-row spacing of $37 \mathrm{~cm}$ had mean plant height of $251.7 \mathrm{~cm} 2$ and number of leaves up to 15 respectively. Therefore, it can be concluded that optimum intra row spacing and Varietal difference combination in the study area for the maximum grain yield was $25 \mathrm{~cm}$ and $14 \mathrm{~cm}$ for Dekalb 920 variety under adequate amount and regular distribution of rainfall. Results showed that variety and spacing were significantly $(P<0.05)$ different.
\end{abstract}

Keywords - Maize, growth, yield, spacing, varieties, savanna.

\section{INTRODUCTION}

Maize (Zea mays $\mathrm{L}$ ) is one of the major cereal crops grown in the humid tropics and Sub-Saharan Africa. It is a versatile crop and ranks third following wheat and rice in world production, (FAO, 2002) Maize is an annual crop of the family Poaceae, commonly known as the grass family and is a key source of food and livelihood for millions of people in many countries of the world.(Adeniyan,2014). The corn plant possesses a simple stem of nodes and internodes. A pair of large leaves extends off of each internode and the leaves total 8-21 per plant. The leaves are linear or lanceolate (lance-like) with an obvious midrib and can grow from 30 to $100 \mathrm{~cm}$ (11.8-39.4 in) in length.
The male and female inflorescences (flower bearing region of the plant) are positioned separately on the plant. The male inflorescence is known as the 'tassel' while the female inflorescence is the 'ear'. The ear of the corn is a modified spike and there may be 1-3 per plant. The corn grains, or 'kernels', are encased in husks and total 30-1000 per ear. The kernels can be white, yellow, red, purple or black in color. Corn is an annual plant, surviving for only one growing season prior to harvest and can reach 2-3 m (7-10 $\mathrm{ft}$ ) in height. The term maize is derived from the Spanish form of the Arawak Native American term for the plant. However, it is popularly called corn in the United States, Canada, New Zealand, and Australia. Corn may also be 
referred to as maize or Indian corn and is believed to originate from Mexico and Central America. According to the FAO reports (2008). Cultural practice improvements like fertilization, using higher yielding varieties and higher plant densities will lead to rise in sweet corn yield (Akman, 2002). The importance of the crop arises from its great productivity over an extremely wide range of environmental conditions. It is grown mainly in the tropics, subtropics, and temperate climates, but the best maize regions are those which receive an annual precipitation of 600 to $1000 \mathrm{~mm}$, except where the crop is irrigated (Sprague and Dudley, 1988).

It is mainly used as a food source and now has become the most important raw material for animal feed (Dutt, 2005) and one of the main sources of cereals for food, forage and processed industrial products. It is produced extensively in Nigeria, where it is consumed roasted, baked, fried, pounded or fermented. Human consumption of corn and corn meal constitutes a staple food in many regions of the world. In advanced countries, it is an important source of many industrial products such as corn sugar, corn oil, corn flour, starch, syrup, brewer's grit and alcohol and the grain is extensively used for the preparation of corn starch, dextrose, corn -flakes, gluten, grain cake, lactic acid and acetone which are used by various industries such as textile, foundry, fermentation and food industries. Corn oil is used for salad, soapmaking and lubrications (Dutt, 2005).

World production of maize is around 790 million tones (Chiezey, 2010). By 2050 demand for maize will double its presence demand in the developing world and the crop is predicted to become the crop with the greatest production globally and in the developing world by 2025(Abuzar et al., 2011) and the world area of maize production was 176 million ha while that of wheat was 216 million ha and rice at 184 million ha as reported in in 2017. About $70 \%$ of the world maize production area is found in the developing countries. However, these countries contribute to only $49 \%$ of the world's maize production (FAOSTAT, 2016).

Global maize consumption is projected to increase by $1.3 \%$ per annum over the projection period, a slower pace compared to $3.3 \%$ p.a . in the previous decade. This increase is principally driven by higher feed demand, which holds the largest share of total utilization, rising from 56\% in the base period to around 58\% in 2027. Developing countries account for over three quarters of the increase in feed consumption due to fast expanding livestock and poultry sectors. Feed demand is expected to rise 120 metric tons $(\mathrm{mt})$ to $699 \mathrm{mt}$, and major countries that account for the increase are China $(+32 \mathrm{mt})$, the
United States (+20 mt), Argentina (+5 mt), Indonesia (+5 $\mathrm{mt})$ and Viet Nam $(+5 \mathrm{mt})$. Production in Viet Nam and Thailand, in particular, will grow due to fast-expanding poultry industries. Food use of maize is expected to expand mostly in developing countries due to growing populations and maize is becoming increasingly important in diets, especially white maize. Maize will remain an important staple for Sub-Saharan Africa, where consumption of white maize is expanding and where maize accounts for about a quarter of total caloric intake. Overall, African countries show the strongest growth in maize consumption for food among all developing countries at about $3 \%$ per annum(p.a.)

Among all the factors which affect the corn yield remarkably, plant Density is one of the most important ones and due to its genetic potential, corn yield is different under various plant populations (Abuzar et al., 2011). It was reported that new maize cultivars cannot tiller considerably and usually produce one ear/plant at low plant population and interplant competition rows which affected the total yield negatively since it instigates apical dominance, impels barrenness and finally reduce the number of ears/plant and grain/ear (Abuzar et al., 2011). According to the Sangoi (2001) there is no specific optimum population density for all the weather conditions since it differs based on environmental and controlled conditions Low plant density causes minimum corn yield due to the leaf area's little plasticity in each plant (Lashkari et al., 2011).

Therefore, the objectives of the experiment include;

$\checkmark$ to compare the performance of the varieties of maize used in this trial as influenced by the different intra- row spacing

$\checkmark$ to determine best intra-row spacing for optimum growth and yield for maize hybrids production in Nigeria

$\checkmark$ to determine the best hybrid maize variety that will give optimum growth and yield of the Crop

\section{METHODS}

\section{Location of the study}

The field experiment was conducted at the Research Farm of the Faculty of Agriculture, University of Abuja, in the Southern Guinea Savanna Zone of Nigeria, during the cropping season of 2018.It has boundary with Kogi state in the south, Kaduna in the north, Nasarawa in the east and Niger state by the west. Its total area is about 724,473.9 hectares. The major food crops are mainly corn, yams, millet, beans, cassava, garden eggs, soya beans, melon, okra, groundnuts and vegetables. The major occupation 
among the people within the study area is farming. The farm lies on latitude $6^{\circ} 45^{\prime} \mathrm{N}$ and $7^{\circ} 39^{\prime} \mathrm{E}$ and Longitude $8^{\circ} 25^{\prime}$ and $9^{\circ} 20^{\prime}$ North, $300 \mathrm{~m}$ altitude. The average temperature is between $28^{\circ} \mathrm{C}$ to $30^{\circ} \mathrm{C}$ in the dry season and can be as high as $40^{\circ} \mathrm{C}$ or more especially in Gwagwalada area, with sandy loamy soil. The rainy season begins from April and ends in October with mean annual rainfall of $1,100 \mathrm{~mm}$ to $1,800 \mathrm{~mm}$ (Barnabas and Nwaka,2014), humidity of $14 \%$ at planting period and wind of $10 \mathrm{~km} / \mathrm{h}$ north east. During the rainy season, the area witnesses uneasy hot temperature beginning early in the morning, through the day and the night becomes warm. About $60 \%$ of the yearly rains fall from the months of July to September and the rest of the year is relatively cold and dry. The vegetation of Abuja is dominated by species of plants such as Albizia zygia, Butrospermum paradocium, Parkia clappertoniana, Terminalia supera, Bombax buonepozenze (Balogun,2001), The vegetation is very important to the people where $60 \%$ depend on it for household energy (fuel wood) and construction materials. The soil in the study area is deep and well drained Sandy Loam that constitute soil that result from the granite and migmatite as the principal rocks in the area. They have moderate runoff potential and the texture of the soil is typically loamy sand, clay loam and sandy clay. Fertility of soil is moderate with acidity rating of 5.60 to 5.80 (Ishaya and Grace, 2007)

\section{Land Preparation}

The Experimental land was manually cleared and mechanically ploughed using a tractor mounted disc plough, and then harrowed twice to break the soil clods. Most of the debris was ploughed back into the soil then the experimental plots were laid out using measuring tape and pegs

\section{Planting Material}

The Planting materials used for the trial were two varieties of maize Dekalb 818 and 920. The maize varieties were obtained from National seed council of Nigeria. Abuja.
Dekalb818 and 920hybrids are extremely adaptable and give superior results all over the World; this comes from proved reliability in dramatically diverse climate conditions that are present during last several years, depending upon location and weather condition.

Dekalb920 is adaptable to a well drain sandy loam soil with average rainfall of $600-1000 \mathrm{~mm}$ and can also grow under irrigation condition, It mature between 80 to 90 days after sowing and is high yielding hybrid with excellent standard ability. Dekalb818 is high drought resistant hybrid, can tolerate poor soil and tolerant to folia disease and stalk rot. It mature within 90 days after sowing with long and cylindrical ears, good grain coloration and more row per cob.

These hybrids are designed for intensive agricultural production and application of all modern agro-technical measures in maize production. Dekalb hybrids had been commercialized since 2008. They arrived into our market with top quality hybrids, from wide European offer, characterized by high seed quality for which were shortly recognized by agricultural producers as the right choice for their fields. In 2010 offer for Africa market are the hybrids from all FAO groups significant for our area (FAO 200 FAO 600).

\section{Treatment and Experimental Design}

The experimental treatments were 6 different intra-rows spacing of $14 \mathrm{~cm}, 18 \mathrm{~cm}, 21 \mathrm{~cm}, 25 \mathrm{~cm}, 30 \mathrm{~cm}$ and $37 \mathrm{~cm}$ by $75 \mathrm{~cm}$ inter row spacing and two maize varieties.

I. Maize varieties denoted as $\mathrm{A}$ which include Dekalb920 $\left(\mathrm{A}_{1}\right)$ and Dekalb 818( $\left.\mathrm{A}_{2}\right)$

II. Six different intra-rows spacing denoted as $\mathrm{B}$, $14 \mathrm{~cm}\left(\mathrm{~B}_{1}\right), \quad 18 \mathrm{~cm}\left(\mathrm{~B}_{2}\right), \quad 21 \mathrm{~cm}\left(\mathrm{~B}_{3}\right), 25 \mathrm{~cm}\left(\mathrm{~B}_{4}\right)$, $30 \mathrm{~cm}\left(\mathrm{~B}_{5}\right)$ and $37 \mathrm{~cm}\left(\mathrm{~B}_{6}\right)$

Thus, a 2 × 6 factorial combination trial was used for the treatments and making a total of 12 treatment combinations.

Table 1: Treatment Combinations

\begin{tabular}{ccc}
\hline Combination & Varieties & Intra-row spacing \\
\hline $\mathrm{A}_{1} \mathrm{~B}_{1}$ & Dekalb 920 & $14 \mathrm{~cm}$ \\
$\mathrm{~A}_{1} \mathrm{~B}_{2}$ & Dekalb 920 & $18 \mathrm{~cm}$ \\
$\mathrm{~A}_{1} \mathrm{~B}_{3}$ & Dekalb 920 & $21 \mathrm{~cm}$ \\
$\mathrm{~A}_{1} \mathrm{~B}_{4}$ & Dekalb 920 & $25 \mathrm{~cm}$ \\
$\mathrm{~A}_{1} \mathrm{~B}_{5}$ & Dekalb 920 & $30 \mathrm{~cm}$ \\
$\mathrm{~A}_{1} \mathrm{~B}_{6}$ & Dekalb 920 & $37 \mathrm{~cm}$ \\
$\mathrm{~A}_{2} \mathrm{~B}_{1}$ & Dekalb 818 & $14 \mathrm{~cm}$ \\
$\mathrm{~A}_{2} \mathrm{~B}_{2}$ & Dekalb 818 & $18 \mathrm{~cm}$
\end{tabular}




$\begin{array}{lcc}\mathrm{A}_{2} \mathrm{~B}_{3} & \text { Dekalb } 818 & 21 \mathrm{~cm} \\ \mathrm{~A}_{2} \mathrm{~B}_{4} & \text { Dekalb } 818 & 25 \mathrm{~cm} \\ \mathrm{~A}_{2} \mathrm{~B}_{5} & \text { Dekalb } 818 & 30 \mathrm{~cm} \\ \mathrm{~A}_{2} \mathrm{~B}_{6} & \text { Dekalb } 818 & 37 \mathrm{~cm}\end{array}$

Table. 2: Plant Population Per hectares and Per Plots

\begin{tabular}{llcc}
\hline S/N & Spacing $(\mathbf{c m})$ & Plant Population per hectare & Population per plot \\
\hline 1 & $14 \mathrm{~cm}$ & 95,238 plants/ha & 143 plants \\
2 & $18 \mathrm{~cm}$ & 74,074 plants/ha & 112 plants \\
3 & $21 \mathrm{~cm}$ & 63,492 plants/ha & 96 plants \\
4 & $25 \mathrm{~cm}$ & 53,333 plants $/$ ha & 80 plants \\
5 & $30 \mathrm{~cm}$ & 44,444 plants $/$ ha & 68 plants \\
6 & $37 \mathrm{~cm}$ & 36,036 plants/ha & 56 plants \\
\hline
\end{tabular}

\section{Experimental Design}

Randomized Complete Block Design (RCBD) with 3replications was used in the study. Factorial arrangement was used in organizing the treatments which were fitted into the Design Each replicate contained 12 plots, of $3 \mathrm{~m} \times 5 \mathrm{~m}$ sizes giving $15 \mathrm{~m}^{2}$ gross plot and $9 \mathrm{~m}^{2}$ net plot and separated by $1 \mathrm{~m}$ allay pathway. Thus a total of 36 plots were used for the experiment.

\section{Sowing}

Sowing of one seed per hole was done on the $22^{\text {nd }}$ July 2018. The various plant spacing gave the different plant populations. Maize seeds were sown at depth of between $2 \mathrm{~cm}-3 \mathrm{~cm}$ in plots measuring $5 \mathrm{~m} \times 3 \mathrm{~m}$ using six different spacing's listed above.

\section{Fertilizer application}

N: P::K 20:10:10 was applied 14 days after planting at recommended rate for maize at $200 \mathrm{~kg} / \mathrm{ha}$ and Urea $46 \% \mathrm{~N}$ at $150 \mathrm{~kg} / \mathrm{ha}$.

\section{Pest and disease control}

There was incidence of Stem borer (Busseola fusca) and it was controlled by spraying the affected maize plant with Sharp shooter at the rate of $8.8 \mathrm{~kg}$ ai $/$ ha at $6 \mathrm{WAS}$.

\section{Weed control}

Para force and Atrazine were applied as pre-emergence herbicide at the rate of $1.6 \mathrm{~kg}$ ai $/ \mathrm{ha}$ and later supplemented with manual weeding using hoe at $4 \mathrm{WAS}$ and $8 \mathrm{WAS}$.

\section{Data Collection}

\section{Growth Parameters}

Plant Height (cm)
Six plants were chosen at random from the net plots at the center of the gross plot. Plant height for each plant was measured from the ground level of the plant to the tip of central spike tassel. The mean height of the six plants was recorded.

\section{Number of Leaves per Plant}

Six plants were randomly selected within the Net plot and number of leaves in each selected plant was counted. The mean number of leaves per plant was obtained.

\section{Leaf Area Index}

Six leaves from six randomly selected plants in the Area of the net plot were measured at the fourth leaf from the top of the plant, because it is fully expanded. Maximum length and width of the leaf were determined to obtain the leaf area. The Maize leaf area was estimated by multiplying the length and width of the leaf and the product was adjusted by a factor 0.75 according to Francis et al (1960). This was done for all the leaves taken and added up to give the leaf area per plant. The leaf area per plant was divided by area of ground cover to get the leaf area index (LAI)

$\mathrm{LA}=$ maximum length $\times$ maximum width $\times 0.75$

Where 0.75 is a fixed factor

$$
L A I=\frac{\text { Leaf Area }}{\text { Area of Ground Covered }}
$$

\section{Stem Diameter (cm)}

Stem girth was measured on the selected plants using tape and was reported in millimeters. 


\section{Plant Stand Count}

From each plot the number of stands was counted to determine the plant population per plot.

\section{Grain Yields (tons/ha)}

The grain yield was determined by using the dry grain weight after harvesting, threshing and winnowing in the air to remove chaff using a Mettle Toledo sensitive balance and converted to tons/ha.

\section{Statistical Analysis}

The data collected were subjected to Statistical analysis for Analysis of Variance (ANOVA) using SAS - Statistical Analytical Structure procedure and the means were separated using Duncan Multiple Range Test (DMRT)

\section{RESULTS}

Effect of intra- row spacing on the growth of maize varieties

\section{Stand Count}

The results showed that variety and spacing were significantly $(\mathrm{P}<0.05)$ different throughout the period of the evaluation and positively affected the stand count. The effect of intra-row spacing on the stand count of two maize varieties Dekalb 920 and Dekalb 818 is shown in table 3. The two varieties gave statistically similar percent stand count in respect to the intra-row spacing however, varying intra-row spacing shows significant differences in emergence of two maize varieties. Spacing $14 \mathrm{~cm}$ gave the highest count stand while $37 \mathrm{~cm}$ gave the least stand count of maize

Table 3 Effect of Intra-row Spacing and Varietal difference on Stand Count/Plot of maize

\begin{tabular}{lll}
\hline Spacing $(\mathbf{c m})$ & Variety 1 & Variety 2 \\
\hline 14 & 138.67 & 139.67 \\
18 & 107.00 & 108.00 \\
21 & 94.00 & 92.33 \\
25 & 75.33 & 76.00 \\
30 & 64.67 & 63.00 \\
37 & 52.33 & 53.00 \\
Grand Mean & 88.67 & 88.67 \\
LSD ( $\alpha<0.05)$ & 2.95 & 2.88 \\
\hline
\end{tabular}

Means with the same letter in a column of each factor are not significantly different at $(\mathrm{P} \leq 0.05), \mathrm{LSD}=$ Least Significant Difference, V1= Dekalb 920, V2 = Dekalb 818
Effects of Variety and Spacing and Varietal difference on Plant Height $(\mathrm{cm})$ of Maize

The effects of variety and spacing on plant height of two maize varieties are shown in Table 4. There were significant differences also in the plant height of the maize varieties investigated. Variety 920 gave taller plants of $287.7 \mathrm{~cm}$ at 9 th weeks after sowing, followed by 818 with height of $281.7 \mathrm{~cm}$. With respect to spacing, maize plants sown at $14 \mathrm{~cm}$ in 2018 gave taller than other plants spacing during the 9th weeks with height of $287.7 \mathrm{~cm}$ and $281.7 \mathrm{~cm}$ for variety one and two respectively at $9^{\text {th }}$ weeks. These were followed by plants sown at $18 \mathrm{~cm} ; 21 \mathrm{~cm}$ and $25 \mathrm{~cm}$. Plants sown at $37 \mathrm{~cm}$ were the shortest. The results showed that variety and spacing were significantly $(\mathrm{P}<0.05)$ different throughout the period of the evaluation and positively affected plant height.

Table 4 Effect of Intra-row Spacing and Varietal difference on Plant Height $(\mathrm{cm})$ of maize

\begin{tabular}{lll}
\hline Spacing $(\mathrm{cm})$ & Variety 1 & Variety 2 \\
\hline 14 & 287.7 & 281.7 \\
18 & 275.3 & 275.7 \\
21 & 272.7 & 271.0 \\
25 & 275.0 & 266.0 \\
30 & 268.0 & 260.3 \\
37 & 259.7 & 251.7 \\
Grand Mean & 273.06 & 267.7 \\
LSD ( $\alpha<0.05)$ & 7.53 & 10.11 \\
\hline
\end{tabular}

Means with the same letter in a column of each factor are not significantly different at $(\mathrm{P} \leq 0.05)$, LSD $=$ Least Significant Difference, V1= Dekalb 920, V2 = Dekalb 818

\section{Effects of intra-row Spacing and Variety on Number of Leaves per Plant of Maize \\ The results indicated that variety and spacing were significantly $(\mathrm{P}<0.05)$ different and positively affected number of leaves of maize. The response of number of leaves of two maize varieties to different intra-row spacing is shown in Table 5. The mean number of leaves of maize variety Dekalb 920 and 818 were similar at 9 weeks, which indicated that the trend in the number of leaves did not change. Based on spacing, plants sown at $14 \mathrm{~cm}$ had the highest number of leaves at 9 weeks after sowing in the evaluation. There were significant differences in number of leaves of plants sown at both $14 \mathrm{~cm}$ and other spacing.}


Table 5. Effect of Intra-row Spacing and Varietal difference on Number of Leaves/Plant of maize

\begin{tabular}{lll}
\hline Spacing $(\mathbf{c m})$ & Variety $\mathbf{1}$ & Variety $\mathbf{2}$ \\
\hline 14 & 16.00 & 16.00 \\
18 & 16.00 & 15.33 \\
21 & 15.33 & 15.00 \\
25 & 15.00 & 15.00 \\
30 & 15.00 & 15.00 \\
37 & 15.00 & 15.00 \\
Grand Mean & $\mathbf{1 5 . 3 9}$ & $\mathbf{1 5 . 2 2}$ \\
LSD ( $\boldsymbol{\alpha}<\mathbf{0 . 0 5})$ & $\mathbf{0 . 4 3}$ & $\mathbf{0 . 4 3}$ \\
\hline
\end{tabular}

Means with the same letter in a column of each factor are not significantly different at $(\mathrm{P} \leq 0.05), \mathrm{LSD}=$ Least Significant Difference, V1= Dekalb 920, V2 = Dekalb 818

\section{Effect of intra-row Spacing and Varietal difference on Leaf Area per Plant of Maize}

The response of leaf area of two maize varieties to different spacing is shown in Table 6. There were significant differences in leaf area of the two maize varieties evaluated. In the 9 th week, maize variety 920 had the highest leaf area $(763.30 \mathrm{~cm})$, followed by 818 which had $758.3 \mathrm{~cm}$. Dekalb 818 plants had the smallest leaf area $(690.3 \mathrm{~cm})$. Based on spacing, plants sown at $37 \mathrm{~cm}$ were superior in leaf area with values of $763.30 \mathrm{~cm}$ at 9 WAS. The superiority in leaf area based on spacing was $37 \mathrm{~cm}>$ $30 \mathrm{~cm}>25 \mathrm{~cm}>21 \mathrm{~cm}>18 \mathrm{~cm}>\mathrm{x} 14 \mathrm{~cm}$. The results showed that variety and spacing were significantly $(\mathrm{P}<$ 0.05 ) different and positively affected leaf area of maize.

\section{Table 6 Effect of Intra-row Spacing and Varietal} difference on leaf area $(\mathrm{cm})$ of maize

\begin{tabular}{lll}
\hline Spacing $(\mathrm{cm})$ & Variety 1 & Variety 2 \\
\hline 14 & $\mathbf{7 0 4 . 0 0}$ & $\mathbf{6 9 0 . 3}$ \\
18 & $\mathbf{7 1 7 . 3 0}$ & $\mathbf{7 1 5 . 0}$ \\
21 & $\mathbf{7 2 6 . 0 0}$ & $\mathbf{7 2 3 . 3}$ \\
25 & $\mathbf{7 3 9 . 7 0}$ & $\mathbf{7 3 3 . 0}$ \\
30 & $\mathbf{7 5 3 . 3 0}$ & $\mathbf{7 4 5 . 0}$ \\
37 & $\mathbf{7 6 3 . 3 0}$ & $\mathbf{7 5 8 . 3}$ \\
Grand Mean & $\mathbf{7 3 3 . 9}$ & $\mathbf{7 2 7 . 5}$ \\
LSD $(\boldsymbol{\alpha}<\mathbf{0 . 0 5})$ & $\mathbf{8 . 9 6}$ & $\mathbf{2 0 . 3 5}$ \\
\hline
\end{tabular}

Means with the same letter in a column of each factor are not significantly different at $(\mathrm{P} \leq 0.05), \mathrm{LSD}=$ Least Significant Difference, V1= Dekalb 920, V2 = Dekalb 818.
Effect of Intra-row Spacing and Varietal difference on leaf Area Index of maize

Table 7 shows the effect of intra-row spacing on leaf area Index (LAI) of two maize varieties. Varietal differences did not result in significant differences in LAI in the evaluation. Varying spacing caused significant differences in LAI, with each decrease in spacing significantly increasing LAI in sampling period. The results showed that variety and spacing were significantly $(\mathrm{P}<0.05)$ different and positively affected leaf area index of maize.

Table 7 Effect of Intra-row Spacing and Varietal difference on leaf Area Index of maize

\begin{tabular}{lll}
\hline Spacing $(\mathbf{c m})$ & Variety 1 & Variety 2 \\
\hline 14 & 14.03 & 13.77 \\
18 & 13.07 & 13.00 \\
21 & 12.50 & 12.33 \\
25 & 12.20 & 12.13 \\
30 & 11.57 & 11.40 \\
37 & 11.27 & 11.10 \\
Grand Mean & 12.44 & 12.29 \\
LSD $(\alpha<0.05)$ & 0.18 & 0.45 \\
\hline
\end{tabular}

Means with the same letter in a column of each factor are not significantly different at $(\mathrm{P} \leq 0.05), \mathrm{LSD}=$ Least Significant Difference V1= Dekalb 920, V2 = Dekalb 818

Effects of intra-row Spacing and Varietal difference on Stem Diameter of Maize

The effect of intra-row spacing on stem girth of maize is shown in Table 8.Variety 920 had the highest stem girth of $11.20 \mathrm{~cm}$, while variety $818 \mathrm{had} 11.00 \mathrm{~cm}$ at 9 th week after sowing. Based on spacing, maize plants sown at spacing of $37 \mathrm{~cm}$ were superior in stem girth while plants sown at spacing of $14 \mathrm{~cm}$ had the smallest stem girths. The results showed that variety and spacing were significantly $(\mathrm{P}<$ 0.05 ) different and positively affected stem girth of maize.

Table 8 Effect of Intra-row Spacing and Varietal difference on Stem Diameter (cm) of maize

\begin{tabular}{lll}
\hline Spacing $(\mathrm{cm})$ & Variety 1 & Variety 2 \\
\hline 14 & 8.20 & 8.03 \\
18 & 8.70 & 8.57 \\
21 & 9.13 & 9.03 \\
25 & 9.77 & 9.50 \\
30 & 10.33 & 10.23 \\
37 & 11.20 & 11.00 \\
\hline
\end{tabular}




\begin{tabular}{lll}
\hline Grand Mean & 9.56 & 9.39 \\
LSD $(\alpha<0.05)$ & 3.07 & 2.63 \\
\hline
\end{tabular}

Means with the same letter in a column of each factor are not significantly different at $(\mathrm{P} \leq 0.05)$, LSD $=$ Least Significant Difference, V1= Dekalb 920, V2 = Dekalb 818

The analysis revealed that the effect of intra- row spacing, variety and the plant density was significant $(\mathrm{P}<0.05)$ for grain yield as shown in (table 9). Mean comparisons showed that Dekalb 920 maize variety at $25 \mathrm{~cm}$ spacing had the highest yield of (8.00ton/ha average) and was followed by $14 \mathrm{~cm}$ spacing which had ( 7.70 ton/ha average) which was due to grain weight. Also, Dekalb 818 variety at $14 \mathrm{~cm}$ spacing had the third highest yield $(7.33 \mathrm{ton} / \mathrm{ha}$ average) and was followed by $18 \mathrm{~cm}$ spacing which had (7.27ton/ha average). The result shows that the two varieties at $14 \mathrm{~cm}$ intra- row spacing had a higher grain yield compared to the $37 \mathrm{~cm}$ intra- row spacing which means that the trend of changes in the two maize varieties to row spacing was similar and positively affected grain yield of maize.

Table 9 Effect of Intra-row Spacing and Varietal difference on Grain Yield (t/ha) of maize

\begin{tabular}{lll}
\hline Spacing $(\mathrm{cm})$ & Variety 1 & Variety 2 \\
\hline 14 & 7.70 & 7.33 \\
18 & 6.30 & 7.27 \\
21 & 6.63 & 6.27 \\
25 & 8.00 & 7.13 \\
30 & 6.03 & 5.33 \\
37 & 5.97 & 6.30 \\
Grand Mean & 6.77 & 6.61 \\
& & \\
LSD $(\alpha<0.05)$ & 1.12 & 0.94
\end{tabular}

Means with the same letter in a column of each factor are not significantly different at $(\mathrm{P} \leq 0.05)$, LSD $=$ Least Significant Difference V1= Dekalb920, V2 = Dekalb 818

\section{DISCUSSION}

\section{Effect of Intra-row Spacing and Varietal Difference on the Growth and Yield of Maize}

The differential growth with respect to plant height observed among the two varieties may be attributed to differences in genetic characteristics of the individual varieties, including rapid growth rates, tallness or shortness of the varieties. This is similar to the findings of Majambu et al.(1996) and Ibrahim et al.(2000) that attributed the differences in growth indices of crops to genetic constitution. Maize plants spaced $14 \mathrm{~cm}$ intra-row spacing were taller than other plants possibly because of increased competition for space, sunlight and available nutrients. This is similar to the findings of Teasdale (1995), Widdicombe and Thelen (2002), and Dalley et al. (2006) who attributed the increased growth rates and earlier canopy closure of narrow row spaced crops to quest for increased light interception as well as increased availability of soil moisture because of equidistant distribution of crop plants. It is also consistent with the reports of Al-Rudha and Al-Youmis (1998) that maize sown at $15 \mathrm{~cm}$ had the highest plant height compared with their counterparts sown at wider intra-row spacing.

The increase in plant population with the decrease of plant spacing obtained in this study is obvious since plant spacing is used as a tool to increase or decrease plant density. These results were supported by Roy and Quazem (1987).Roy and Biswas (1992) and Larson and Hanway (1977) who reported that, narrow plant spacing had resulted in high plant population. On the other hand, plant population is always a function of seed germination percentage and will not be affected when the plant is sown on the top of the ridge or on the bottom of the ridge, unless the soil is saline. Salt accumulation on the top of the ridge may result in poor seed germination and consequently low plant population. Therefore, these significant differences in plant population between the two varieties and the intrarow spacing between plants in this study might probably be due to the fact that seedlings emergence and establishment of the two varieties were similar.

The similarity observed in the number of leaves of the two maize varieties may be attributed to growth characters which are being influenced by genetic make-up of the plants. This is similar to the findings of Sajjan et al., (2002) who reported that, growth characters of crops are based on their genetic make-up. Maize plant sown on $14 \mathrm{~cm}$ spacing had higher number of leaves than their counterparts which were sown at wider spacing possibly because of increased growth rate in search for space, sunlight and other environmental resources. This is consistent with the findings of Al-Rudha and Al-Youmis (1998) and Ali et al. (2003) that made similar reports on $15 \mathrm{~cm}$-spaced maize plants.

The differences observed in leaf area of the two varieties of maize sown could be attributed to the differences photosynthetic activities of leaves, differences in chlorophyll content and activity of photosynthetic enzymes. This is similar to the findings of Gwizdek (1989) who attributed the differences between the leaf area and 
other growth characters of maize genotypes to differences in photosynthetic activity of leaves, chlorophyll content, stomata conductance value and activity of photosynthetic enzymes. The differences observed in leaf area is also similar to the findings of Akinfoesoye et al., (1997); Odeleye and Odeleye (2001) who suggested that, since maize varieties differ in leaf area, other growth characters as well as in yield and its components, breeders must select most promising combiners in their breeding programs. Increased intra-row spacing resulted in larger leaf area possibly because there was a reduction in competition for space, sunlight and nutrients within the wider spaced plants. This is similar to the findings of Ali et al., (2003) who reported that, competition between maize plants for light, soil fertility and other environmental factors were markedly increased with highest population but decreased with lower plant population.

Leaf area index is an important parameter of maize. In our research, increase in LAI explains the general crop trends that increasing plant density increases leaf area index on account of more area occupied by green canopy of plants per unit area. On the other hand, increasing leaf area index is one of the ways of increasing the capture of solar radiation within the canopy and accumulation of dry matter. Responses of dry matter accumulation and leaf area index were similar when plant density was increased or intra-row spacing was decreased. These results are in close conformity with the results obtained by Winter and Ohleroch (1999) who found that LAI in maize increases with increase in plant density. The increasing of LAI was attributed to the rise in total leaf area/plant (Alam, Haider, 2006; Yasari, Patwardhan, 2006).

The highest leaf area index obtained in $14 \mathrm{~cm}$ intra-row spacing by the two varieties in this study could be due to variation in environmental factors, influenced by genotype, plant population, climatic condition and soil fertility. Higher plant population produced which offset the effect of large leaf area produced at $37 \mathrm{~cm}$ intra-row spacing. This result is supported by Winter and Ohlrogge (1973) and Scarbook and Doss (1973) who reported that leaf area index increased with the increase of plant population. The significant differences in leaf area and leaf area index between plant spacing were reported.

The superiority of Dekalb 920 maize variety over 818 maize variety with respect to stem diameter may be attributed to the special qualities credited to hybrids. This was probably due to the fertility of the soil used for the experiment which resulted in an equal ratio between the leaves and the stems of the two varieties. This is similar to the findings of Obi (1999), Kim (1997), Olakojo et al. (1998) and Udoh (2005) who reported that some hybrid maize varieties have yield advantage over other maize varieties because they possess special qualities as high yield, disease resistance, and early maturity, uniformity in flowering and ear placement, and ease of harvesting using combined harvester. Maize plants sown at spacing of $37 \mathrm{~cm}$ were superior in stem girth over those sown at narrower or smaller spacing possibly because the plants obtained more soil moisture and nutrients than narrower-spaced plants. This is similar to the findings of Barbier et al. (2000); Hamayan (2003); Dalley et al. (2006) and Azam et al. (2007) who reported that, wider-spaced maize plants obtained more soil moisture and nutrients than narrower plants. Also, Kunuskan, O, (2000) reported that, stem diameter were lower in higher plant densities as a consequence of interplant competitions.

\section{Effect of Intra-row Spacing and Varietal Differences on Yield of Maize}

The superiority of Dekalb 920 maize variety over 818 maize with respect to grain yield may be attributed to the special qualities credited to the hybrids, including disease resistance, early maturity, uniformity in flowering and earplacement, and very high yield and the genetic make-up of the Variety. This is similar to the findings of Obi (1999), Kim (1997), Olakojo et al. (1998) and Udoh (2005) who reported that, some hybrid maize varieties have yield advantage over other maize varieties because they possess such special qualities as high yield, disease resistance, and early maturity, uniformity in flowering and ear placement. Maize plants sown at spacing of $25 \mathrm{~cm}$ were superior in grain yield and closely followed by maize sown at spacing $14 \mathrm{~cm}$. However, the higher grain yield obtained at closer intra-row spacing $(25 \mathrm{~cm}$ and $14 \mathrm{~cm})$, could be attributed to higher number of plants and harvestable cobs at optimum spacing. This result was in conformity with the findings of Okanet.al. (2004) that obtained highest grain yield from closest intra-row spacing of $20 \mathrm{~cm}$. There was no significant differences in yield ha- 1 between the two varieties. This finding confirmed the result obtained by Mani et al. (2002), who observed a non-significant increase in grain yield ha-1 between maize varieties of Dekalb. The higher cob and grain yields so obtained at $25 \mathrm{~cm}$ and $14 \mathrm{~cm}$ could also be due to fact that more cobs are harvested under this population (Mani et al., 2002, Iqtas and Acar, 2006, Valentinus and Tollenaar, 2006, Onyango, 2009). . Optimum plant density for maximum grain yield per unit area may differ from hybrid to hybrid on account of significant interactions between hybrids and densities (Farnham, 2001; Widdicombe and Thelen, 2002; Tokatlidis et al., 2005) Therefore from the result so obtained from this study it is therefore eminent that higher grain yield for the newly developed extra-early maize variety is possible at $25 \mathrm{~cm}$ and $14 \mathrm{~cm}$ intra-row spacing. 


\section{CONCLUSION}

The result of present study showed that Intra-row spacing and Variety had significant influences on most of the growth parameters, yield and yield components of maize. The result also indicated that variety Dekalb 920 was the more suitable of the two maize varieties tested, and $14 \mathrm{~cm}$ and $25 \mathrm{~cm}$ intra-row spacing was better to achieve optimum yield.

\section{RECOMMENDATIONS}

Therefore, from the result so obtained from this study it is eminent that higher grain yield for the Dekalb 920 maize variety is possible at $14 \mathrm{~cm}$ and $25 \mathrm{~cm}$ intra-row spacing $\mathrm{x}$ 1 plants per hole which can be adopted by farmers

\section{REFERENCES}

[1] Abuzar M R, Sadozai G U, Baloch M S, Baloch A A, Shah I H, Javaid T, Hussain N. (2011). Effect of plant population densities on yield of Maize. Journal. Animal. Plant Science. 21(4): 692-965.

[2] Adeniyan O.N (2014). Effect of different population densities and fertilizer rates on the Performance of different maize verities in two rain forest Agro-Ecosystem of South West Nigeria. Africa. Journal. Plant Science. 8(8):410-415.

[3] Akman Z. 2002. Effect of tiller removing and plant density on ear yield of Sweet Corn (Zea mays L. Saccharata Sturt). Pakage. Journal. Biolological. Science. 5 (9): 906908.

[4] Alam S.M.N., Salim M., Islam N., Rahman M.N (2007) International Journal of Sustainability in Crop Production 2(6) 31-33.

[5] Ali, R., Khahil, S. K., Raza, S. M. and Khan, H. (2003).Effects of herbicides and row spacing on maize (zea mays L).Pakistan Journal of Weed Science Research, 9(34): 171-178.

[6] Al-Rudha, M. S. and Al-Youmis, A. H. (1998). The effect of row spacing and nitrogen levels on yield, yield components and quality of maize (Zeamays L.). Iraqi Journal of Agricultural Science, 13: 235-252.

[7] Balogun O (2001). The Federal Capital Territory of Nigeria: A Geography of Its Development. University of Ibadan Press Limited.pp4-6

[8] Barnabas I. M. \& Nwaka G.I.C.(2014) Characterization of the soils of University of Abuja farm in the Capital Territory, Abuja. Proceedings of the $38^{\text {th }}$ Annual Conference of the Soil Science of Nigeria. 10-14 March,2014, University of Uyo, Akwa Ibom State. Efficiency in Maize as Affected by Nitrogen Availability and Row Spacing. Agronomy Journal.100 (4): 1094-1100.

[9] Chiezey U.E., The Plant Scientist 2(1\&2) (2001) 121-133.

[10] Dalley, C. D., Bernards, M. I. and Kells, J. J. (2006).Effect of Weed removal timing and row spacing on soil moisture in corn (Zea mays).Weed Technology, 20: 399 409. DIPA (2006)..

[11] Dutt, S. (2005).A Handbook of Agriculture.ABD Publishers, India. Pp 116-118.

[12] Edmeades GO, Bolanos J, Elings A, Ribaut JM, Banziger $M$. The role and regulation of the an thesis silking interval in maize. In: Westgate ME, Boote KJ, editors. Physiology and Modelling Kernel Set in Maize. Madison, WI: CSSA; 2000. p. 43-73.

[13] FAO (2002).Fertilizer and the future.IFA/FAO Agriculture Conference on Global food security and the role of Sustainability Fertilization. Rome, Italy. 16th-20th March, 2003, pp 1-2.

[14] FAOSTAT (Food and Agriculture Organization of the United Nations) (2016)

[15] Food and Agriculture Data, .https://www.fao.org/faostat/en/ \#home $/ 2 / 4 / 6$

[16] Gwizdek, S. (1989).Role of photosynthesis in some maize lines and their hybrids.Hodowla Roslin Aklimatyzacja nasiennictwo, 33(5-6): 61-72.

[17] Ibrahim, K. Amans, A. and Abubakar, I. U. (2000).Growth indices and yield of Tomato (Lycopesicon esculentum karest) varieties as influenced by crop spacing at samaru.

Proceedings of the 18th HORTSON Conference Proceedings (1): 40-47.

[18] Ishaya, S. and Gracae, M. (2007). Assessment of People's Perception on Linkages Between Environmental Sustainable and Socio-economy Development in Gwagwalada Town, FCT. Ecol. ENv. Cons. 14(1): $227-$ 234.

[19] Larson, W. E. and Hanway, J. J. (1977).Corn production. In: G.F. Sprague (ed). Corn and corn improvement. Agron. J. 18:625-669.

[20] Lashkari M, Madani H, Ardakani M R, Golzardi F, Zargari K. 2011. Effect of plant density on yield and yield components of different Corn (Zea mays L.) hybrids.AMEuras. J. Agric. \& Environ. Sci. 10 (3): 450-457.

[21] Majambu, I. S., Ogunlella, V. B. and Ahmed, M. K. (1996). Responses of Two Okro (Abelmoschus esculentus (L) Moench) varieties to fertilizer growth and nutrient concetration as influenced by nitrogen and phosphorus applications. Fertilizer Research, 8(3):

[22] Odeleye, F. O. and Odeleye, M. O. (2001).Evaluation of morphological and agronomic characteristics of two exolic and two adapted varieties of maize(Zea mays) in South

West Nigeria.Proceedings of the 19th Annual Conference of HORTSON. (1): 140-145.

[23] Roy and Biswas, P. K. (1992).Effect of plant density and detopping following silking on cob growth fodder and grain yield of maize.J. Agric. Sci. 119:297 - 301.

[24] Roy, S. K. and Quasem, A. (1987). Effect of plant population and leaf pruning on yield and yield attributes of maize. Agron. J. 2:34

[25] Sajjan A. S., Shekhargounda, M. and Badanur (2002). Influence of data of sowing, spacing and levels of nitrogen on yield attributes and seed yield of Okro. Ikamataka Journal of Agricultural Science, 15(2): 267-274. 
[26] Sangoi L, Ender M, Guidolin AF, Almeida ML, Heberte PC (1996).Influence of reduced spacing in corn yield in regions with short summers. Braz. Agric. Res. 36(6):861869.

[27] Sangoi L, Salvador J (1998). Influence of plant height and of leaf number of maize production at high plant densities. Agron. J. 33:297-306.

[28] Sangoi, L., Salvador, R. J. (1998a). influence of plant height and leaf number on maize production at high plant densities. Pesquisa Agropecuaria Brasileria, Brasila,V.33, n.3, P. 297 -306.

[29] Sangoi L (2000). Understanding plant density effects on maize growthand development: an important issue to maximise grain yield. Ciênc.Rural 31(1): 159-168.

[30] Sangoi L. 2001. Understanding plant density effects on maize growth and development: an important issue to maximize grain yield. Ciencia Rural.31(1): 159-168.

[31] Scarbook, C. E, and Doss, B. D. (1973). Leaf area index and radiation as related to corn yield. Agron. J. 65:459461.

[32] Singh RP, Singh RK (2006). Ecological approaches in weed management. National Symposium on Conservation Agriculture and Environment, Oct. 26-28 pp. 301-306.

[33] Sprague, G. F and Dudley, J. W. (1988). Corn and Corn Improvement ed. P. 653 - 682. Madison, Wisconsin, USA.

[34] Teasdale,I. R. (1995). Influence of narrow now/high population corn (Zea mays) on weed control and light transmittance. Weed Technology, 9: 113-118.

[35] Winter, S. R. and A. J. Ohlrogge, A. J. (1973). Leaf angle, Leaf area and corn (Zea Mays L.). Agron. J. 65:395 - 397. . 